\title{
IMPLEMENTATION OF THE RESPONSIBILITY TO PROTECT IN THE SETTLEMENT OF HUMANITARIAN CRISIS IN THE CENTRAL AFRICAN REPUBLIC BY THE UNITED NATIONS
}

\author{
Parulian Yusuf S \\ Junior Associate Robintan Sulaiman \& Partners (RSP) Law Firm, Indonesia \\ Email: lian.deutschland@gmail.com
}

Submitted: January 2, 2019; Reviewed: January 30, 2019; Accepted: February 4, 2019

\begin{tabular}{ll}
\hline \multicolumn{1}{c}{ Article Info } & \multicolumn{1}{c}{ Abstract } \\
\hline Keywords: & $\begin{array}{l}\text { State's sovereignty enables the execution of governance } \\
\text { Responsibility, Crisis, Humanity, UN } \\
\text { arrangements and state's primary) obligation to protect } \\
\text { coI: }\end{array}$ \\
citizens from the threats of genocide, crimes against \\
humanity, war crimes and aggression. Moreover, \\
sovereignty is considered as a state-owned right to reject \\
forms of interventions. The opposition that arises between \\
sovereignty and the protection of humanity encourages the \\
birth of Responsibility to Protect. The humanitarian crisis \\
occurred in the Central African Republic when the Central \\
African Republic government was unable to stop the \\
insurgency arising in its territory. Seleka and Anti-Balaka \\
rebels were involved in the civil war in the Central African \\
Republic. Seleka rebels attacked a predominantly Christian \\
and Anti-Balaka population attacking a Muslim minority. \\
This is of concern to the international community and \\
encourages the United Nations Security Council to take \\
action to resolve the humanitarian crisis in the Central \\
African Republic under Responsibility to Protect.
\end{tabular}

\section{A. Introduction}

Responsibility to protect is a new concept in international law that encourages each country to perform its obligations to protect civilians residing in its territory. Responsibility to Protect is based on 3 (three) main pillars, namely (1) the responsibility of the state to protect its people from mass destruction, war crimes, ethnic cleansing and crimes against humanity; (2) the responsibility of the international community to assist countries in carrying out their duties; and (3) the responsibility of each member State of the United Nations to respond collectively, on time and decisively. ${ }^{1}$ However, the implementation of Responsibility to Protect especially the second and third pillars still creates a conflict between the principle of state sovereignty and humanitarian intervention.

In principle, sovereignty is absolute, indivisible and immutable. In addition, sovereignty consists of rights and obligations of a state. Through this sovereignty, the state can exercise power within the territory and citizens. In addition to the exercise of such powers, the state must protect its citizens from the threat of crimes of genocide, war crimes, crimes against humanity and ethnic cleansing against certain racial, religious, political and classical backgrounds. ${ }^{2}$

The central African Republic is a country that is geographically located on the African Continent.

\footnotetext{
${ }^{1}$ Implementing the Responsibility to Protect Report of the Secretary General UN Doc A/63/677/2009.

${ }^{2}$ Rahayu, "EKSISTENSI PRINSIP RESPONSIBILITY TO PROTECT DALAM HUKUM INTERNASIONAL", $M M H 41$, no. 1 (2012): 128-136, 129, DOI: 10.14710/mmh.41.1.2012.128-136
} 
The country is experiencing poverty and political instability after gaining independence from France. ${ }^{3}$ The appointment of the president was done through a military coup and a revolt. In 2013, Seleka's group, which is a combination of several rebel groups from the east and the north Central African Republic, including the Convention of Patriots for Justice and Peace (CPJP), the Union of Democratic Forces for Unity (UDFR), the Democratic Front of Central African People FDPC), the patriotic Convention for the Salvation of Kodro (CPSK) and the Alliance for Renaissance and Reorganization (A2R), an Islamic minority group headed by Michel Djotodia held a rebellion to overthrow the Francois Bozize Regime. ${ }^{4}$ Seleka rebels succeeded in mastering the strategic cities, government and state capitals, Bangui. President Bozize fled, and Seleka leader Michel Djotodia announced that he was president of the Central African Republic and dissolved Seleka to reunite the people of Central African Republic. ${ }^{5}$ The dissolution of Seleka by President Djotodia was rejected by members of Selaka. The refusal prompted the village's Anti-Balaka security forces to fight against the rest of Seleka rebels. Anti-Balaka considers that when the Seleka rebels committed a coup, they also massacred thousands of Christians and burned down the homes of the cypress. This has led to widespread and widespread conflict, from political conflicts between opposition and government to Christian-Muslim conflict.

The Government of the Central African Republic is the highest authority in the administration of the state that should be able to play an important role in ensuring the protection of its citizens. However, political and security instability in the Central African Republic is a major problem in the prevention of humanitarian crises. This encourages rebel groups that no longer target government but civilians with a particular religious background. The inability of the Government of the Central African Republic to protect its citizens as well as from Seleka and Anti-Balaka groups became an indicator that the Central African Republic failed to implement Responsibility to Protect. This prompted the international community to assist the Central African Republic to carry out its obligations. According to the report of the Secretary-General, the Civil War of the Central African Republic was categorized as a war crime, ethnic cleansing, mass extermination and crimes against humanity that we're unable to be resolved by the then ruling government. ${ }^{6}$ The conflict continues to this day and threatens the existence of the Central African Republic to split into a Christian state and an Islamic State. The international community ${ }^{7}$ can act through the United Nations Security Council. The Security Council issued a number of resolutions to stop the humanitarian crisis in the Central African Republic. What is the legal position of Responsibility to Protect in international law? How is the implementation of Responsibility to Protect in settlement of the humanitarian crisis in the Central African Republic by the United Nations?

\section{B. Discussion}

\section{Legal Position of Responsibility to Protect in International Law}

\section{a. Responsibility to Protect in International Customary Law}

Human rights are a natural right. It is applied universally and inherits directly towards humanity. ${ }^{8}$ Efforts to respect and protect human rights are the obligation and responsibility of the community, government and state. ${ }^{9}$ Efforts to uphold human rights and protect humanity from the threat of genocide, crimes against humanity and war are part of running a business to maintain world peace and security. In practice, some countries do not agree because it threatens the sovereignty of the state. However, the International Court of Justice in the case of military and paramilitary activities in and against Nicaragua states:

"In international law, there are no rules, other than such rules as may be accepted by the state

\footnotetext{
${ }^{3}$ Dean Stahl, Karen Kerchelich, Abbreviations Dictionary (New York, Washington D.C: CRC Press, 2001), 1435.

${ }^{4}$ Ibid.

${ }^{5}$ Annette Weber and Markus Kaim, "CENTRAL AFRICAN REPUBLIC IN CRISIS. AFRICAN UNION MISSION NEEDS UNITED NATIONS SUPPORT,” SWP Comments, (2014): 1-7, 2.

${ }^{6}$ United Nations General Secretary Report No. A/67/920-S/2013/399.

${ }^{7}$ Article 2 (7), United Nations Charter.

8 Virgayani Fattah, "HAK ASASI MANUSIA SEBAGAI JUS COGENS DAN KAITANNYA DENGAN HAK ATAS PENDIDIKAN," Yuridika 32, no. 2 (2017): 355-378, 356, DOI: 10.20473/ydk.v32i2.4775.Fattah.

${ }^{9}$ Felishella Earlene and Jesslyn Evelina Tandrajaya, "SENGKETA PENGUASAAN TANAH ANTARA WARGA KAPUK POGLAR RT 07 / RW 04 JAKARTA BARAT DENGAN POLDA METRO JAYA DITINJAU DARI PERSPEKTIF HAK ASASI MANUSIA," Cepalo 3, no. 2 (2019): 55-62, 57, DOI: 10.25041/cepalo.v3no2.1844.
} 
concerned, by treaty or otherwise, whereby the level of armaments of a sovereign State can be limited, and this principle is valid for all states without exceptions."

The International Court of Justice understands opinions as an element of customary international law. ${ }^{10}$ Therefore, international customary law has 2 (two) components which are always the benchmarks of the implementation of customary international law which is the practice by the state and opini iuris siven ecessitatis (opino iuris). ${ }^{11}$ The existence of Responsibility to Protect in customary international law can be seen from 2 (two) aspects:

1) States must protect each other from international criminal practice. If the state has the responsibility of protecting its citizens and failing to implement it, the international community is obliged to provide legal sanctions.

2) States have the legality to act under customary international law when the United Nations Security Council agrees to intervene in humanity. Example: Resolutions 1970 and 1973 on the Implementation of Responsibility to Protect in Libya. In addition, customary international law has the peculiarity of allowing humanitarian intervention without waiting for the resolution of the United Nations. For example, intervention conducted by the North Atlantic Treaty Organization (NATO) to Kosovo in 1999 received international condemnation. The NATO action led by the United States and its allies has no basis for humanitarian intervention in Kosovo. Such action is also contrary to the principles contained in the Charter of the United Nations. However, such violations, on the other hand, encourage the transformation of the law regarding the commitment to upholding humanitarian protection as contained in the Charter of the United Nations on Human Rights.

Ius Cogens is based on the acceptance of fundamental values that are in common with the concept of public order in national law so that an international agreement can be void if contrary to ius cogens. Therefore, Ius Cogens is recognized as a norm that should not be violated. ${ }^{12}$ Ius Cogens which is universally applicable as a result of pacta sunt servanda law of Articles 53 and 64 of the Vienna Convention 1969. According to Verdross, there are 3 (three) rules that can be ius cogens:

(1) Basic rules arising from the common interest in the international community, (2) the emergence of humanitarian goals, (3) in harmony with the Charter of the United Nations. ${ }^{13}$ Ius Cogens can be born out of customary international law aimed at protecting the interests of the international community. ${ }^{14}$ Ulrich Scheuner divides ius cogens into three groups: $:^{15}$

1) The first group: on the basis of consideration of the highest interest of the state to protect the foundations of law, peace and humanity as a minimum standard of international law. Examples: Prohibition of genocide, slavery, use of illegal or arbitrary violence.

2) The second group consists of principles and rules of law that are essential for maintaining peace cooperation which in international law aims to protect the public interest. Example: The use of tools by pirates.

3) The third group includes the imperative norm to protect humanity, especially the most essential human rights.

They encourage full protection of humanity. As a peremptory norm, Ius cogens provides the legal force to the principles of customary international law such as banning crimes against humanity, war crimes, genocide, slavery and torture. This is in accordance with the Responsibility to Protect object that prevents genocide, crimes against humanity, war crimes and ethnic cleansing. Based on the above, the Responsibility to Protect is an emerging part of customary international law. However, according to the authors, Responsibility to Protect's existence must be strengthened through international agreements. In comparison, the concept of insight of the archipelago (archipelagic country) which is the doctrine of Mochtar Kusumaatmadja has a stronger legal standing through the United Nations

\footnotetext{
${ }^{10} \mathrm{http} / / /$ law.cornell.edu/wex/opinio_juris_internationaal_law, Accessed on January 12, 2017.

${ }^{11}$ Jeffrey L. Dunoff, Steven R. Ratner, David Wippman, International Law: Norms, Actors, Process: A Problem Oriented Approach (Canada: Wolters Kluwer, 2010), 77-79.

${ }_{12}$ Article 53 of Vienna Convention 1969 on the Law of Treaties.

${ }^{13}$ Mochtar Kusumaatmadja, Hukum Laut Internasional. (Bina Cipta: Jakarta, 1986), 176.

${ }^{14}$ Ibid.

${ }^{15}$ Ulrich Scheuner, "Conflict of Treaty Provisions with a Peremptory Norm of General International Law and its Consequences: Comments on Arts. 50, 61 and 67 of the ILC"s 1966 Draft Articles on the Law Treaties", ILC\&apos;s Draft Articles on the Law of Treaties - Comments, (1967): 520-532, 525-526.
} 


\section{Convention on The Law of The Sea $1982 .{ }^{16}$}

\section{b. Responsibility to Protect in International Convention}

International conventions are placed as the highest law instruments for the state to enter into international cooperation. Its nature is written so as to facilitate in the proof. International conventions contain general legal principles such as ius cogens, pacta sunt servanda, good faith, and the principles of free consent. ${ }^{17}$ The initial concept of Responsibility to Protect can be seen in the Marten Clause contained in the preamble of The Hague Convention 1899. The Marten Clause codified the law of humanity and the necessity for the public conscience: ${ }^{18}$

"Until a complete code of the laws of war has been issued, the High Contracting Parties think it right to declare that, in cases not included in the Regulations adopted by them, populations and belligerents remain under the protection and empire of the principles of international law, as they result from the usages established between civilized nations from the laws of humanity, and the requirements of the public conscience."

Marten Clause has shaped the direction of international human rights law and international humanitarian customs. Inside the Marten Clause establish the duty and responsibility of the state. The Charter of the United Nations is the legal basis for the Security Council to fulfil its obligations in relation to threats to international security or breaches of peace and security and aggression in accordance with the purposes and principles of the United Nations. ${ }^{19}$ The Security Council is permitted to use armed forces to ensure the stability of international peace and security. $\left.{ }^{20}\right]$

However, there is no single international agreement that explicitly writes Responsibility to Protect. It is because Responsibility to Protect is new and seeks recognition and position in international law. Responsibility to Protect can be found in several documents such as the International Commission on Intervention and State Sovereignty (ICISS) report; The High- Level Panel Report on Threat, Challenges and Change; World Summit Final Act/Outcome Document; Kofi Annan's report as Secretary-General of the United Nations: In Larger Freedom: Towards Development, Security, and Human Rights for All. These documents can "t be categorized as sources of international law because they do not meet the formal and material elements of international legal sources. ${ }^{21}$ Responsibility to Protect has no position in international treaties. However, states subject to international treaties of human rights have an obligation to implement the contents of the agreement under the principle of pacta sunt servanda. ${ }^{22}$ These international agreements include:

1) The Convention on the Prevention of the Crime of Genocide 1948;

2) International on Civil and Political Rights;

3) International Covenant on Economic, Social, and Cultural Right;

4) Convention against Torture and other Cruel Inhuman or Degrading Treatment or Punishment;

5) International Convention on the Elimination of All Forms of Racial Discrimination;

6) Convention on the Elimination of All forms Discrimination Women;

7) Rome Statute 1998;

8) Geneva Convention, 1949.

Countries still have a Responsibility to Protect citizens from threats of genocide, crimes against humanity, war crimes and ethnic cleansing as a form of good faith in the implementation of international treaties.

\section{c. Responsibility to Protect in the General Principles of Law Recognized by Civilized Nations}

The principles of common law recognized by civilized nations were first recognized in the

\footnotetext{
${ }^{16}$ United Nations Convention on the Law of The Sea 1982.

${ }^{17}$ Vienna Convention 1969 on the Law of Treaties.

${ }^{18}$ Convention with Respect the Laws and Customs of War on Land (Hague II) 1899.

${ }^{19}$ Article 26 United Nations Charter.

${ }^{20}$ Article 42 United Nations Charter.

${ }^{21}$ Martin Dixon, Textbook on International Law. Fifth Edition (Oxford: Oxford University Press, 2004), 23-24.

${ }^{22}$ Abdul Muthalib Tahar, Hukum Internasional dan Perkembangannya (Lampung: Fakultas Hukum Universitas Lampung, 2015), 12.
} 
Permanent Court of International Justice (PCIJ) Statute to avoid the problem of non-liquets ${ }^{23}$ in a case confronted by a judge. The judge can not refuse a case by reason of no law. If a judge does not find a relevant treaty with the case then international customs can be used against the case and judges may use general legal principles to strengthen judge's judgment. ${ }^{24}$ The existence of the principle of common law recognized by civilized nations is contained in Article 38 of the Statute of the International Court of Justice (ICJ). Some common law principles include pacta sunt servanda, good faith, par im non imperial habet, lex specialis, lex priori, lex superiori and nebis in idem. ${ }^{25}$

Responsibility to Protect is a new concept in the protection of human rights, especially the implementation of obligations arising from the sovereignty of the state against its citizens. The legal position of Responsibility to Protect is essential since it is implemented by the international community. The author analyzes the position of Responsibility to Protect in the principles of common law recognized by civilized nations by comparison with other doctrines which have become common law principles such as Arvid Pardro's doctrine of the common heritage of humanity in the deep-sea zones and deep ocean seabed. ${ }^{26}$

In 1967, Arvid Pardro formulated the common heritage of humanity in an article known as Maltese's proposal. In the proposal, it is explained that the deep-sea zones and deep ocean seabed are the common heritage of humanity. Some countries oppose the concept of the common heritage of humanity on the grounds of state sovereignty over the sea and resources will be degraded, the absence of the applicable legal regime, and the effectiveness of this doctrine against the privatization of natural resources. ${ }^{27}$

The important development of the common heritage of humanity occurs in the 1970 United Nations General Assembly Declaration on the seabed, seas and submarine lands beyond the jurisdiction of the state. This declaration establishes the common heritage of humanity as the legal basis in the setting of the seabed. The common heritage of humanity's doctrine gained its position as general legal principles by civilized nations through the 1982 law of marine law conventions known as the United Nations on the Law of the Sea $1982 .{ }^{28}$

The concept of Responsibility to Protect has similarities with the common heritage of humanity as an expert opinion. However, to change the legal position of doctrine into a general legal principle recognized by civilized nations requires a long process. The key to this process is that the doctrine is adopted in an international agreement under the United Nations. The common heritage of humanity principle derives from the United Nations on the Law of the Sea 1982.

The author argues that Responsibility to Protect can ${ }^{e t}$ be regarded as a general legal principle recognized by civilized nations. This is based on the absence of an international convention under the United Nations, adopting the Responsibility to Protect concept. Therefore, the authors conclude the position of Responsibility to Protect in international law as a doctrine or opinion of experts.

\section{d. Responsibility to Protect as International Doctrine}

The doctrine or opinion of international jurists is the source of the subsidiary law of primary law sources (International Customs, International Covenants and General Legal Principles recognized by the Civilized Nations). The doctrine could not stand alone as the basis of the verdict, because it merely reinforces the source of the primary law. ${ }^{29}$ The doctrine or opinion of jurists can be used to explain the rules of international law and facilitate the establishment of international law. ${ }^{30}$ Examples of expert opinions that have been used include the Committee of Jurists appointed by the League of Nations Council of 1920 to provide disputed opinions on Aaland Island. ${ }^{31}$

Currently, the implementation of Responsibility to Protect can only be done by the United Nations

\footnotetext{
${ }^{23}$ Alfredo Mordechai Rabello, "NON LIQUET: FROM MODERN LAW TO ROMAN LAW", Annual Survey of International and Comparative Law 10, no. 2 (2004): 1-26, 11-12.

${ }^{24}$ Sefriani. Hukum Internasional Suatu Pengantar (Jakarta: Raja Grafindo Persada, 2012), 49

${ }^{25}$ Wahyu Sasongko, Dasar-Dasar Ilmu Hukum (Lampung: Universitas Lampung, 2013), 29.

${ }^{26} \mathrm{http} / / /$ wealthofhtecommons.org/essay/common-heritage-mankind-bold-doctrine-kept-within-strict-boundaries, Accessed on March 23, 2017.

${ }^{27}$ Ibid.

${ }^{28}$ Ibid.

${ }^{29}$ Serfiani, Op.Cit., 50.

${ }^{30}$ Abdul Muthalib Tahar, Op.Cit., 44.

${ }^{31}$ Ibid. 
Security Council through the relevant resolutions. The position of Responsibility to Protect as an additional legal source will strengthen the international agreement on which the Security Council considers to produce a conflict-related resolution that threatens international peace and security. Subsequently, the Security Council assigns the Secretary-General the task of overseeing and reporting the implementation of Responsibility to Protect. The Security Council has implemented Responsibility to Protect in several conflicts as in Libya (2011), Côte d'Ivoire (2011), South Sudan (2011), Yemen (2011), Syria (2012), Burundi (2015), Democratic Republic of Congo (2017), and Central African Republic (2013-2018). ${ }^{32}$

Based on the above analysis, the authors argue that the position of Responsibility to Protect as the doctrine of international law. The existence of Responsibility to Protect in international law reinforces the legal force of the Security Council to take the necessary measures to safeguard international peace and security.

2. Implementation of Responsibility to Protect in the Center African Republic by United Nations

Genocide crimes, ethnic cleansing, war crimes and crimes against humanity are a threat to international peace and security. This is based on Security Council Resolution No. 827, violations of extraneous international humanitarian law and ethnic cleansing practices in Bosnia and Herzegovina pose a threat to international peace and security. Resolution 955, the Security Council established that genocide and violations of international humanitarian law systematically and pervasively pose a threat to international peace and security.

Humanitarian intervention is one form of international community involvement to protect human rights within a country facing humanitarian crises such as crimes of genocide, crimes against humanity, war crimes and ethnic cleansing. The act of such intervention is subject to the provisions of the Charter of the United Nations. This means that the Security Council may determine a situation occurring in a country to constitute a threat to international peace and security and may take action under Article 41, namely:

"The Security Council may decide what measures not involving the use of armed force are to be employed to give effect to its decisions, and it may call upon the Members of the United Nations to apply such measures. These may include complete or partial interruption of economic relations and of rail, sea, air, postal, telegraphic, radio and other means of communication, and this variance of diplomatic relations."

The actions of non-military intervention are the first step to stop the situation threatening international peace and security. If such non-military intervention fails, the United Nations may take action under Article 42 of the Charter of the United Nations or Article 42, namely:

"Should the Security Council consider that measures provided for in Article 41 would be inadequate or have proved to be inadequate, it may take such action by air, sea, or land forces as may be necessary to maintain or restore international peace and security. Such action may include demonstrations, blockade, and other operations by air, sea, or land forces of Members of the United Nations."

Under paragraph 139, the Final Act World Summit 2005, the international community must take collective action through the United Nations Security Council, if the national authorities have failed to protect populations within its territory from crimes of genocide, war crimes, ethnic cleansing and crimes against humanity. Chapter VII, The Charter of the United Nations, authorizes the Security Council to take collective action under certain circumstances. Article 39 of the Charter provides that:

"The Security Council shall determine the existence of any threat to the peace breach of the peace, or act of aggression and shall make a recommendation, or decide what measures shall be taken in accordance with articles 42 and 42, to maintain or restore international peace and security."

Thus, the crimes of genocide, war crimes, ethnic cleansing and crimes against humanity constitute a threat to international security and peace and have legal consequences under Chapter VII of the Charter of the United Nations.

\footnotetext{
${ }^{32}$ http://www.globalr2p.org/publications/652, Accessed on May 12, 2017.
} 
Measures to be adopted to implement the Responsibility to Protect by the United Nations Security Council include:

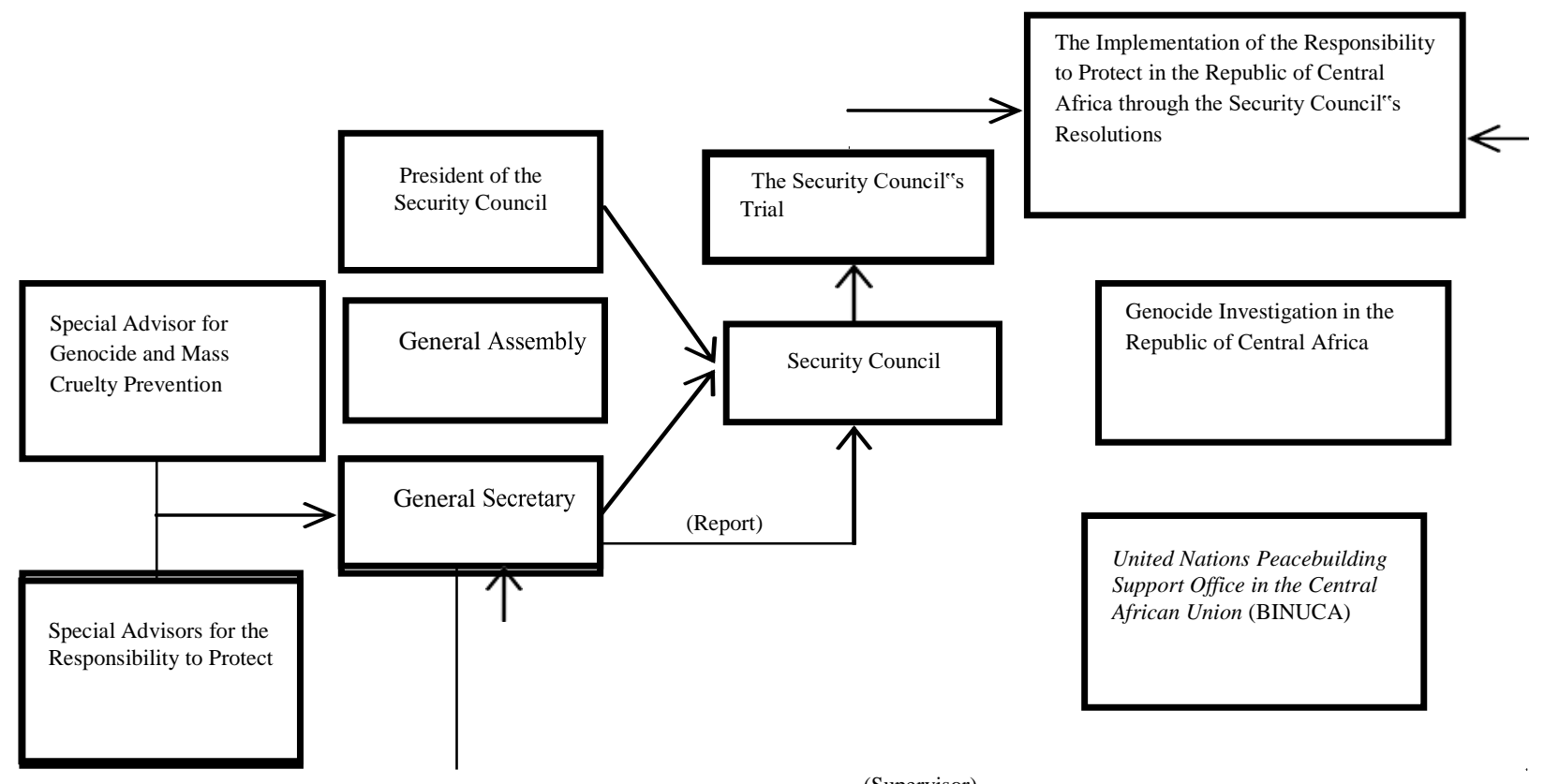

Chart 1.1. the Process of Implementing the Responsibility to Protect by the United Nations

\section{a. Report to the Security Council}

The President of the Security Council may convene a meeting if at the request of a Security Council member, ${ }^{33}$ a dispute or situation of Security Council attention, ${ }^{34}$ the General Assembly makes recommendations and poses a question to the Security Council ${ }^{35}$ and the Secretary-General brings problems that endanger international peace and security. ${ }^{36}$

The humanitarian crisis in the Central African Republic received attention from the SecretaryGeneral. Through the report number S/2011/241, the Secretary-General reports to the Security Council on children and armed conflict occurring in the Central African Republic. This report is the first report of the Secretary-General to the Security Council.

The Secretary-General must report to the Security Council the implementation of such resolution. The reports are made continuously after the Security Council provides other resolutions related to the humanitarian crisis in the Central African Republic.

\section{b. Investigation of Prima Facie Genocide}

Special Advisors on Genocide Prevention and Mass Cruelty and Special Advisor Responsibility to Protect can undertake a fact-finding mission and make recommendations to the Security Council through the Secretary-General. ${ }^{37}$ The two special advisors are established by the Secretary-General and cooperate with international agencies both within the United Nations and outside such as FAO, UNDP, UNESCO, UNFPA, UNICEF, UNHCR and Human Rights Watch to confirm the genocide.

Investigation of the humanitarian crisis in the Central African Republic was implemented by the United Nations Peace Building Support Office in the Central African Union (BINUCA). BINUCA conducts investigations to confirm genocide in the Central African Republic through several fields including politics, socio-economic, human rights, humanitarian, child protection and gender. ${ }^{38}$

\footnotetext{
${ }^{33}$ Article 2 Provisional Rules of Procedures Security Council (S/96/Rev.7).

${ }^{34}$ Article 35 United Nations Charter

${ }^{35}$ Article 11 (2) United Nations Charter

${ }^{36}$ Article 99 United Nations Charter

${ }^{37}$ Note the Secretary-General ${ }^{\text {es }}$ comment that the advisers are to work in collaboration: Letter dated 31 August 2007 from the Secretary-General addressed to the President of the Security Council UN Doc S/2007/721

${ }^{38}$ United Nations General Secretary Report No. S/2011/311
} 
The results of the investigation suggest there has been a massive genocide committed against civilians with a particular religion. The Secretary-General reports to the Security Council to take the necessary measures by issuing resolutions to implement Responsibility to Protect.

\section{c. The Humanitarian Crisis in the Central African Republic is an International Crime}

The central African Republic is one of the poorest countries in the world.$^{39}$ The political, security, health and economic crises have been an unfinished problem since gaining independence from France in 1960. The instability caused turmoil in society that eventually led to a coup against a legitimate government. This became a dilemma. Coup d'etat was not done by small groups but also by the military that was supposed to provide security guarantees.

Seleka rebels who carried out a coup against President Bozize controlled several towns before finally succeeding in bringing down Bozize and taking over the government through President Djotodia. However, during the tenure process, Seleka, which is an affiliation of several combatant groups, committed international crimes by killing civilians who were Christians. Anti-Balaka which originally was the village security forces did not participate in the battle. Seleka's actions targeting civilians caused social upheaval, which caused Anti-Balaka to turn into a militia group against Seleka's group. However, Anti-Balaka targets were not just Seleka's group but also Muslim civilians. This changed the direction of combat in the Central African Republic. Originally a political background became a religious background.

Seleka and Anti Balaka groups committed international crimes as set out in the Rome Statute 1998. Each of them committed mass killings and was widespread against one group with a religious background. The Government of the Central African Republic is unable to exercise sovereignty as a form of responsibility to protect its citizens from crimes of genocide, war crimes, crimes against humanity and ethnic cleansing. Therefore, the international community moves to end the humanitarian crisis and create stability in the Central African Republic

\section{d. Implementation of Responsibility to Protect through Security Council Resolution}

The Security Council requested the Secretary-General to report and update the situation report in the Central African Republic. ${ }^{40}$ The report forms the basis for the Security Council implementing Responsibility to Protect through resolutions against the Central African Republic. The United Nations Security Council has issued 18 resolutions related to the humanitarian crisis in the Central African Republic. However, only 11 resolutions containing Responsibility to Protect, these are Resolution 2121; Resolution 2127; Resolution 2134; Resolution 2149; Resolution 2196.

Resolution 2217; Resolution 2262; Resolution 2301; Resolution 2339; Resolution 2387; Resolution 2399. Resolutions containing Responsibility to Protect have several indications, among others (1) The existence of the phrase "the primary responsibility to protect the civilian population"; "The transnational Authorities have the primary responsibility for protecting the population."; "The transnational Authorities have the primary responsibility to protect the civilian population" Central African Republic "; "In these resolutions there are elements Responsibility to Protect that is Responsibility to Prevent through the development of state institutions, Responsibility to

React through sanctions arms embargo, travel ban and asset freeze and Responsibility to Rebuild through Disarmament, Demobilization, Reintegration and Repatriation program.

\section{Conclusion}

Responsibility to Protect is the doctrine of international law because the doctrine of Responsibility to Protect is used to analyze cases by mapping and interpreting, systematizing the law under abstract general principles of law, and developing moral philosophy and philosophy of justice. In addition, the Responsibility to Protect to strengthen the Security Council resolution to intervene in the domestic affairs of a country related to the conflict that threatens international peace and security.

The United Nations Security Council has issued 18 resolutions related to the humanitarian crisis in the Central African Republic. However, only 11 (eleven) resolutions use Responsibility to Protect. The Responsibility to Protect Responsibility to Prevent is through Responsibility to Prevent development

\footnotetext{
${ }^{39}$ https://www.heritage.org/index/pdf/2018/countries/centralafricanrepublic.pdf, Accessed on June 12, 2017.

${ }^{40}$ United Nations General Secretary Report No. S/2013.261.
} 
through state institutional development, Responsibility to React through sanction of arms embargo, travel ban and asset freeze and Responsibility to Rebuild through Disarmament, Demobilization, Reintegration and Repatriation program.

\section{A. Journal}

\section{References}

Annette Weber and Markus Kaim, "CENTRAL AFRICAN REPUBLIC IN CRISIS. AFRICAN UNION MISSION NEEDS UNITED NATIONS SUPPORT,” SWP Comments, 2014: 1-7.

Earlene, Felishella., Tandrajaya, Jesslyn Evelina. "SENGKETA PENGUASAAN TANAH ANTARA WARGA KAPUK POGLAR RT 07 / RW 04 JAKARTA BARAT DENGAN POLDA METRO JAYA DITINJAU DARI PERSPEKTIF HAK ASASI MANUSIA," Cepalo 3, no. 2, 2019: 55-62, DOI: 10.25041/cepalo.v3no2.1844.

Fattah, Virgayani. "HAK ASASI MANUSIA SEBAGAI JUS COGENS DAN KAITANNYA DENGAN HAK ATAS PENDIDIKAN," Yuridika 32, no. 2, 2017: 355-378, DOI: 10.20473/ydk.v32i2.4775.

Rabello, Alfredo Mordechai. "NON LIQUET: FROM MODERN LAW TO ROMAN LAW". Annual Survey of International and Comparative Law 10, no. 2, 2004.

Rahayu. "EKSISTENSI PRINSIP RESPONSIBILITY TO PROTECT DALAM HUKUM INTERNASIONAL", Masalah-Masalah Hukum 41, no. 1, 2012: 128-136. DOI: $10.14710 / \mathrm{mmh} .41 .1 .2012 .128-136$

Scheuner, Ulrich. "Conflict of Treaty Provisions with a Peremptory Norm of General International Law and its Consequences: Comments on Arts. 50, 61 and 67 of the ILC"s 1966 Draft Articles on the Law Treaties", ILC\&apos;s Draft Articles on the Law of Treaties - Comments, 1967: 520-532.

\section{B. Book}

Dean Stahl and Karen Kerchelich. Abbreviations Dictionary. New York, Washington D. C.: CRC Press, 2001.

Dixon, Martin. Textbook on International Law. Oxford: Oxford University Press. Fifth Edition, 2004.

Dunoff, Jeffrey L. Steven R. Ratner., Wippman, David. Wippman, International Law: Norms, Actors, Process: A Problem Oriented Approach. Canada: Wolters Kluwer, 2010.

Kusumaatmadja, Mochtar. Hukum Laut Internasional. Bina Cipta: Jakarta, 1986.

Sasongko, Wahyu. Dasar-Dasar Ilmu Hukum. Lampung: Universitas Lampung, 2013.

Sefriani. Hukum Internasional Suatu Pengantar. Jakarta: RajaGrafindo Persada, 2012.

Tahar, Abdul Muthalib. Hukum Internasional dan Perkembangannya. Lampung: Fakultas Hukum Universitas Lampung, 2015.

\section{Regulation}

Implementing the Responsibility to Protect Report of the Secretary General UN Doc A/63/677/2009.

Note to the Secretary-General"s comment that the advisers are to work in collaboration: Letter dated 31 August 2007 from the Secretary-General addressed to the President of the Security Council UN Doc S/2007/721.

United Nations Charter.

United Nations Convention on the Law of The Sea 1982.

United Nations General Secretary Report Number A/67/920- S/2013/399.

United Nations General Secretary Report Number S/2011/311 United Nations General Secretary Report Number S/2013.261 Provisional Rules of Procedures Security Council (S/96/Rev.7) Vienna Convention 1969 on the Law of Treaties.

\section{Internet}

http://law.cornell.edu/wex/opinio_juris_internationaal_law, Accessed on January 12, 2017.

http://wealthofhtecommons.org/essay/common-heritage-mankind- bold-doctrine-kept-within-strictboundaries, Accessed on March 23, 2017.

http://www.globalr2p.org/publications/652, Accessed on May 12, 2017.

https://www.heritage.org/index/pdf/2018/countries/centralafricanrepublic.pdf, Accessed on June 12, 2017. 
